\title{
An Efficient Protocol for Isolation of High Quality Genomic DNA from Seeds of Apple Cultivars (Malus $\times$ Domestica) for Random Amplified Polymorphic DNA (RAPD) Analysis
}

\author{
Irfan Ahmad Ansari* and M. Salman Khan \\ Department of Biotechnology, Integral University, Lucknow, 226020, India
}

\begin{abstract}
Genomic DNA represents the total genome of an organism and is valuable for different molecular studies. The isolation of high quality DNA is a prerequisite for these molecular techniques. The seeds of apple (Malus $\times$ domestica) contain high amount of polysaccharides, polyphenols and other secondary metabolites that can hamper DNA isolation, amplification, restriction digestion and subsequent molecular studies. Here, we report a simple, inexpensive and an efficient protocol for the isolation of high quality genomic DNA from seeds of different apple cultivars for random amplified polymorphic DNA (RAPD) analysis. This procedure purifies greater amounts of DNA which can be amplified via PCR or digested with endonucleases. The yield of DNA was 200-300 ng/ $\mu \mathrm{L}$ (total 8-12 $\mu \mathrm{g}$ DNA from 1-2 apple seeds). The simplicity of the procedure makes it very practical for DNA extraction.
\end{abstract}

Keywords: Malus, Apple seeds, DNA isolation, Restriction enzymes, RAPD, PCR

\section{INTRODUCTION}

The domesticated apple (Malus $\times$ domestica Borkh., Rosaceae) is a common fruit crop in the temperate world. It has been an important part of the human diet for thousands of years; however, its consumption is linked to the prevention of various chronic diseases [1]. A number of pharmaceutical products from apples such as apple peel and seed extracts are available in the world market. Apple intake has been shown to reduce cancer incidence, cardiovascular disease, symptoms of chronic obstructive pulmonary disease, and the risk of thrombotic stroke [2-6]. Apples contain a large concentration of several classes of polyphenolic compounds such as flavonoids and phenolic acids. Some of the most well studied antioxidant compounds in apples include quercetin-3galactoside, quercetin-3-glucoside, quercetin-3-rhamnoside, catechin, epicatechin, procyanidin, cyanidin-3-galactoside, coumaric acid, chlorogenic acid, gallic acid, and phloridzin $[1,4,7-14]$. The concentration of these phytochemicals may depend on many factors including cultivars. Thus, it is important to have genetic analysis of various apple cultivars to develop apples as pharmaceutical crops.

There are several molecular marker techniques being used to determine the genetic architecture of wide varieties of closely related individuals. Some of these methods have been successfully applied in revealing genetic identities and diversity in apple species [15-17]. With the ever growing requirements for environmental protection and food safety in the production of high quality apples, modern apple breeding has become more dependent on disease resistance genes [18]. Therefore, accurate characterization of the available genetic pool is important in breeding programs and essential

\footnotetext{
*Address Correspondence to this author at the Department of Biotechnology, Integral University, Lucknow, 226020, India; Tel: +91-9456241184; Fax: +91-522-2890809; E-mail: ahmadirfan.amu@gmail.com
}

for the protection of future property rights over new cultivars $[19,20]$.

The traditional methods for characterization and assessment of genetic variability based on morphological, physiological and agronomic traits are often not adequate, since these traits are developmentally regulated or influenced by the genotype $\times$ environment interaction and agronomic practices like selected rootstock or pruning. Molecular markers provide an opportunity for genetic characterization and allow direct comparison of different genetic material independent of environmental influences. DNA markers are also more abundant than morphological and biochemical markers and the whole genome can be assessed easily. Restriction fragment length polymorphisms (RFLPs) have been used with some success for apple cultivar identification and parentage analysis [21-23]. The random amplified polymorphic DNA (RAPD) analysis has already been proved to be valuable in apple genome analysis. These markers have been used to study relationships in the genus Malus, for identification of apple cultivars, apple rootstocks and for paternity analysis [15, 24-29]. Simple-sequence repeat (SSR, microstellites) markers have been successfully used on apple species for identification and positional comparison of major genes and quantitative trait loci (QTLs) for scab, powdery mildew, and fire blight resistance as well as morphological or physiological traits [30-38].

The isolation of high quality genomic DNA is a prerequisite for these molecular techniques. However, high amounts of polysaccharides, polyphenols and various secondary metabolites such as alkaloids, flavonoids and tannins in tree species usually interfere with DNA isolation [39-41]. Polyphenols released from the vacuoles during the cell lysis process are oxidized by cellular oxidases and undergo irreversible interactions with nucleic acids causing browning of the DNA $[39,42]$. The presence of gelling polysaccharides 
prevents complete dissolution of nucleic acids and imparts a viscous constituency to the DNA making it stick to the wells during gel electrophoresis [39, 42-44]. These residual polyphenols, polysaccharides and secondary metabolites have also been reported to interfere with the activity of several biological enzymes like polymerases, ligases and restriction endonucleases [39, 40, 42, 44].

Researchers often modify a protocol or blend two or more different procedures to obtain DNA of the desired quality [42]. A good isolation protocol should be simple, rapid and efficient, yielding appreciable levels of high quality DNA suitable for molecular analysis. So far, there is no report of DNA isolation from seeds of apple. The seeds of Malus species contain high amount of polysaccharides, polyphenols, and other secondary metabolites that can hamper DNA isolation, amplification, restriction digestion and subsequent molecular cloning [40, 45]. So here, we report an efficient and new protocol for isolating high molecular weight PCR amplifiable DNA from seeds of different apple cultivars. We developed this protocol by thoroughly optimizing the existing protocols for plant DNA extraction [40, 41, $43,44,46]$. While adapting the existing protocols for DNA isolation from apple seeds, it was observed that the final DNA preparation was having lot of mucilage with low yield and recalcitrant to restriction digestion and amplification. Hence, we performed several optimization steps to develop a new protocol with increased yield.

\section{MATERIALS AND METHODS}

\section{Plant Materials}

For DNA extraction, seeds from different varieties of Malus $\times$ domestica available in the region of Uttar Pradesh, India, were collected such as 'Red Delicious' (Jammu \& Kashmir), 'Golden Delicious' (Jammu \& Kashmir), 'Red Delicious' (Himachal Pradesh), 'Maharaji' (Jammu \& Kashmir), 'Kali Devi', 'Chocolaty', 'Panchmukhi' and Chinese apple. The voucher specimens were deposited at Department of Botany, Deen Dayal Upadhyay Gorakhpur University, Gorakhpur, U.P., India.

\section{Reagents and Chemicals}

The chemicals and reagents used in the isolation of DNA were: $1 \mathrm{M}$ Tris-HCl pH 8.0, 0.5 MEDTA pH 8.0, 10\% sodium dodecyl sulphate (SDS), $5 \mathrm{M} \mathrm{NaCl}$ solution, extraction buffer (100 mM Tris- $\mathrm{HCl} \mathrm{pH}$ 8.0, $50 \mathrm{mM} \mathrm{Na}$ EDTA pH 8.0; $1.5 \mathrm{M} \mathrm{NaCl}, 1 \%$ SDS, $1 \% \beta$-mercaptoethanol), 7.5 M Ammonium acetate, TE buffer $(10 \mathrm{mM}$ Tris $\mathrm{HCl}, 1 \mathrm{mM}$ EDTA $\mathrm{pH} 8.0), 10 \times$ TAE buffer $\mathrm{pH}$ 8.0, Ethidium bromide (10 $\mathrm{mg} / \mathrm{mL})$, RNase A (2 mg/mL), TE buffer for PCR (10 mM Tris $\mathrm{HCl}, 0.05 \mathrm{mM}$ EDTA, pH 8.3), Chloroform: Isoamyl alcohol (24:1 v/v). Random decamer primers, dNTPs (10 $\mathrm{mM})$, Taq DNA polymerase $(3 \mathrm{U} / \mu \mathrm{L}), 10 \times$ PCR buffer, Restriction enzymes and $10 \times$ Restriction endonuclease buffer were from Bangalore Genei, India. All the chemicals used were of high quality grade purchased from Himedia Inc., Qualigens and Merck, India.

\section{Genomic DNA Isolation from Apple Seeds}

DNA was isolated from fresh seeds of different apple cultivars by thoroughly optimizing the existing protocols for plant DNA extraction [40, 41, 43, 44, 46]. This rapid extraction method of apple seed DNA consists of three steps: extraction of DNA by lysis buffer, precipitation by using high salt concentration and purification by chloroform: isoamyl alcohol. The whole protocol is as follows:

Fresh apple seeds (0.1 gm, 1-2 seeds) was collected and peeled off in sterile condition and homogenized in $25 \mu \mathrm{L}$ of freshly prepared $1.0 \% \beta$-mercaptoethanol. After grinding, $750 \mu \mathrm{L}$ of extraction buffer $(100 \mathrm{mM}$ Tris- $\mathrm{HCl} \mathrm{pH} 8.0,50$ $\mathrm{mM}$ EDTA, $1 \% \mathrm{SDS}, 1.5 \mathrm{M} \mathrm{NaCl}$ ) is added to the homogenate. Transferred the homogenate into a fresh eppendorf tube and incubated at $37{ }^{\circ} \mathrm{C}$ for one hour. One half volumes of freshly prepared $7.5 \mathrm{M}$ Ammonium acetate was added to the homogenate. The mixture was incubated on ice for $30 \mathrm{~min}$. and centrifuged for $10 \mathrm{~min}\left(10,000 \mathrm{rpm}\right.$, at $\left.4{ }^{\circ} \mathrm{C}\right)$. The supernatant was transferred to fresh tube and added double volume of absolute ethanol. The tube was left on ice for $20 \mathrm{~min}$ then at $-20^{\circ} \mathrm{C}$ for $30 \mathrm{~min}$ or over night to precipitate the DNA completely. After centrifugation at $10,000 \mathrm{rpm}$ for $10 \mathrm{~min}$, the supernatant was discarded and DNA pellet was vacuum dried. Resuspend the pellet in $500 \mu \mathrm{L}$ of TE buffer $(10 \mathrm{mM}$ Tris- $\mathrm{HCl} \mathrm{pH}$ 8.0, $1 \mathrm{mM}$ EDTA $\mathrm{pH}$ 8.0). Two microliters of RNase A ( $2 \mathrm{mg} / \mathrm{mL})$ was added to the solution and incubated at $37^{\circ} \mathrm{C}$ for $30 \mathrm{~min}$. One volume of Chloroform: Isoamyl alcohol (24:1) was added and emulsified by inverted shaking to remove RNase and other impurities. Centrifuged the mixture at $10,000 \mathrm{rpm}$ for $5 \mathrm{~min}$ and took the upper aqueous layer. This process of purification was repeated once again. In the aqueous layer, added double volume of absolute alcohol and left on ice for $20 \mathrm{~min}$ and then at $-20{ }^{\circ} \mathrm{C}$ for $30 \mathrm{~min}$ or overnight. After centrifugation at $10,000 \mathrm{rpm}$ for $1 \mathrm{~min}$ the pellet was washed with $1 \mathrm{~mL} 80 \%$ ethanol and vacuum dried. The DNA pellet was re-dissolved in $30 \mu \mathrm{L}$ TE buffer.

\section{DNA Quantification}

The quantification of genomic DNA was achieved using a spectrophotometer (Shimadzu UV-240). The yield was determined by measuring the absorbance at $A_{260}$ and $A_{280}$. The level of DNA purity was determined by the $A_{260} / A_{280}$ absorbance ratio. DNA purity was further tested by running the extracted genomic DNA samples on $0.8 \%$ agarose gel containing $0.5 \mu \mathrm{g} / \mathrm{mL}$ ethidium bromide. A molecular weight marker (Hind III digested lambda DNA) was included on each gel. The gels were visualized and photographed under UV light (Gel documentation system, Bio-Rad).

\section{Restriction Endonuclease Digestion}

The suitability of the extracted genomic DNA for downstream molecular analysis was further determined by restriction digestion using EcoR V, Hind III, Dra I, Bam HI, Bgl II and Kpn I restriction enzymes. The digestion was performed at $37{ }^{\circ} \mathrm{C}$ for $5 \mathrm{~h}$ in a $25 \mu \mathrm{L}$ reaction volume containing $1 \mu \mathrm{g}$ genomic DNA, $2.5 \mu \mathrm{L}$ of $10 \mathrm{X}$ restriction endonuclease buffer and $20 \mathrm{U}$ of restriction endonuclease enzyme. The digested DNA was confirmed on $0.8 \%$ agarose gel with Hind III digested lambda DNA as a marker.

\section{PCR Amplification}

To assess the quality of the isolated DNA for PCR amplification, RAPD profile of eight different apple cultivars was 
Table 1. Comparative Results of the Protocols Followed for DNA Extraction from Apple Seeds

\begin{tabular}{|l|c|c|}
\hline \multicolumn{1}{|c|}{ Methods } & DNA Yield $(\mathbf{n g} / \boldsymbol{\mu L})$ & $\mathbf{A}_{\mathbf{2 6 0}} / \mathbf{A}_{\mathbf{2 8 0}}$ \\
\hline \hline Mishra et al., 2008 [41] & $120-140$ & $1.54-1.60$ \\
\hline Diadema et al., 2003 [44] & $110-125$ & $1.47-1.56$ \\
\hline Pirttila et al., 2001 [40] & $115-130$ & $1.43-1.61$ \\
\hline Barnell et al., $1998[43]$ & $115-120$ & $1.49-1.57$ \\
\hline Kim et al., 1997 [46] & $140-180$ & $1.58-1.64$ \\
\hline Protocol of the Current Study & $200-300$ & $1.75-1.94$ \\
\hline
\end{tabular}

Table 2. Optimization of Extraction Buffer Composition by Modifying the Concentration of Different Constituents (Shown in Bold)

\begin{tabular}{|c|c|c|c|}
\hline No. & $\begin{array}{l}\text { Extraction } \\
\text { Buffer }\end{array}$ & $\begin{array}{l}\text { DNA Yield } \\
(\mathbf{n g} / \mu \mathrm{L})\end{array}$ & $\mathbf{A}_{260} / \mathbf{A}_{280}$ \\
\hline 1 & $\begin{array}{l}200 \mathrm{mM} \text { Tris-HCl pH 8.0, } 25 \mathrm{mM} \text { EDTA, } 250 \mathrm{mM} \mathrm{NaCl}, 0.5 \% \text { SDS (Kim et } \\
\text { al., 1997) }\end{array}$ & $140-180$ & $1.58-1.64$ \\
\hline 2 & 100 mM Tris-HCl pH 8.0, 25 mM EDTA, $250 \mathrm{mM} \mathrm{NaCl}, 0.5 \%$ SDS & $145-175$ & $1.60-1.65$ \\
\hline 5 & $100 \mathrm{mM}$ Tris- $\mathrm{HCl} \mathrm{pH}$ 8.0, $50 \mathrm{mM}$ EDTA, $500 \mathrm{mM} \mathrm{NaCl}, \mathbf{1 . 0} \%$ SDS & $150-190$ & $1.65-1.70$ \\
\hline 6 & $100 \mathrm{mM}$ Tris-HCl pH 8.0, 50 mM EDTA, 1 M NaCl, $1.0 \%$ SDS & $190-225$ & $1.73-1.87$ \\
\hline 7 & $\begin{array}{l}100 \mathrm{mM} \text { Tris- } \mathrm{HCl} \mathrm{pH} 8.0,50 \mathrm{mM} \text { EDTA, } 1.5 \mathrm{M} \mathrm{NaCl}, 1 \% \text { SDS (Current } \\
\text { protocol) }\end{array}$ & $200-300$ & $1.75-1.94$ \\
\hline
\end{tabular}

generated by using six different decamer primers (GTTTCGCTCC, AAGAGCCCGT, CCCGTCAGCA, TCCCGAACCG, AACGCGCAAC and CCCGTCAGCC) [47]. PCR amplification was performed in $25 \mu \mathrm{L}$ reaction volume containing $1 \mathrm{X}$ PCR buffer, $2.5 \mathrm{mM} \mathrm{MgCl}, 0.25 \mathrm{mM}$ each of dNTPs (dATP, dTTP, dCTP, dGTP), $0.2 \mu \mathrm{M}$ primer, $50 \mathrm{ng}$ genomic DNA and 0.75 units of Taq DNA polymerase. Amplification was performed in a thermal cycler (Master cycler, Eppendorff, Germany) programmed for 45 cycles of denaturation at $94{ }^{\circ} \mathrm{C}$ for $1 \mathrm{~min}$, annealing at $34{ }^{\circ} \mathrm{C}$ for $1 \mathrm{~min}$, extension at $72{ }^{\circ} \mathrm{C}$ for $2 \mathrm{~min}$ with an initial denaturation at $94{ }^{\circ} \mathrm{C}$ for $3 \mathrm{~min}$ and final extension at $72{ }^{\circ} \mathrm{C}$ for 8 min. Amplified products were loaded in $1.5 \%$ agarose gel containing $0.5 \mu \mathrm{g} / \mathrm{mL}$ of ethidium bromide and documented by a gel documentation system (Bio-Rad, USA).

\section{RESULTS AND DISCUSSION}

Seeds are storage organs and hence rich in proteins, lipids, polysaccharides, alkaloids and other secondary metabolites. These compounds can interfere with DNA isolation and successive amplification. In the present study, we have successfully isolated DNA from fresh seeds of apple cultivars.

The comparative results of the protocols followed for DNA isolation from apple seeds and optimization of extraction buffer composition by modifying the concentration of different constituents have been shown in Tables $\mathbf{1}$ and 2. In this study, we followed different protocols for genomic DNA isolation out of which method of Kim et al., (1997) was found to give satisfactory results in terms of DNA yield and purity $\left(\mathrm{A}_{260} / \mathrm{A}_{280}\right.$ ratio) (Table 1$)$. Then, we optimized the concentration of extraction buffer constituents by modifying them one by one and finally, developed a new protocol (Table 2).

The DNA extraction from apple seeds employing existing protocols was found to contain lot of mucilage and low yield. Thus the critical change in our modified DNA isolation procedure turned out to be the combined use of high concentration of $\mathrm{NaCl}(1.5 \mathrm{M})$ and ammonium acetate $(7.5 \mathrm{M})$ that significantly increased the efficiency of proteins, secondary metabolites and polysaccharide removal. Further the use of ethanol in contrast to isopropanol was found to be better in precipitating the final DNA yield in the solution. The yield of DNA was 200-300 ng/ $\mu \mathrm{L}$ (total 8-12 $\mu \mathrm{g}$ DNA from 1-2 apple seeds).

The quality of DNA was assessed by spectrophotometry, gel electrophoresis, restriction endonuclease digestion and PCR amplification. A ratio of absorbance $\left(\mathrm{A}_{260} / \mathrm{A}_{280}\right)$ in the range 1.8-2.0 indicates a high level of purity [48, 49]. Spectrophotometer measurements (at $260 \mathrm{~nm}$ and $280 \mathrm{~nm}$ ) of isolated DNA samples of all apple verities gave an absorbance ratio $\left(\mathrm{A}_{260} / \mathrm{A}_{280}\right)$ of 1.75-1.94 indicating high purity. 


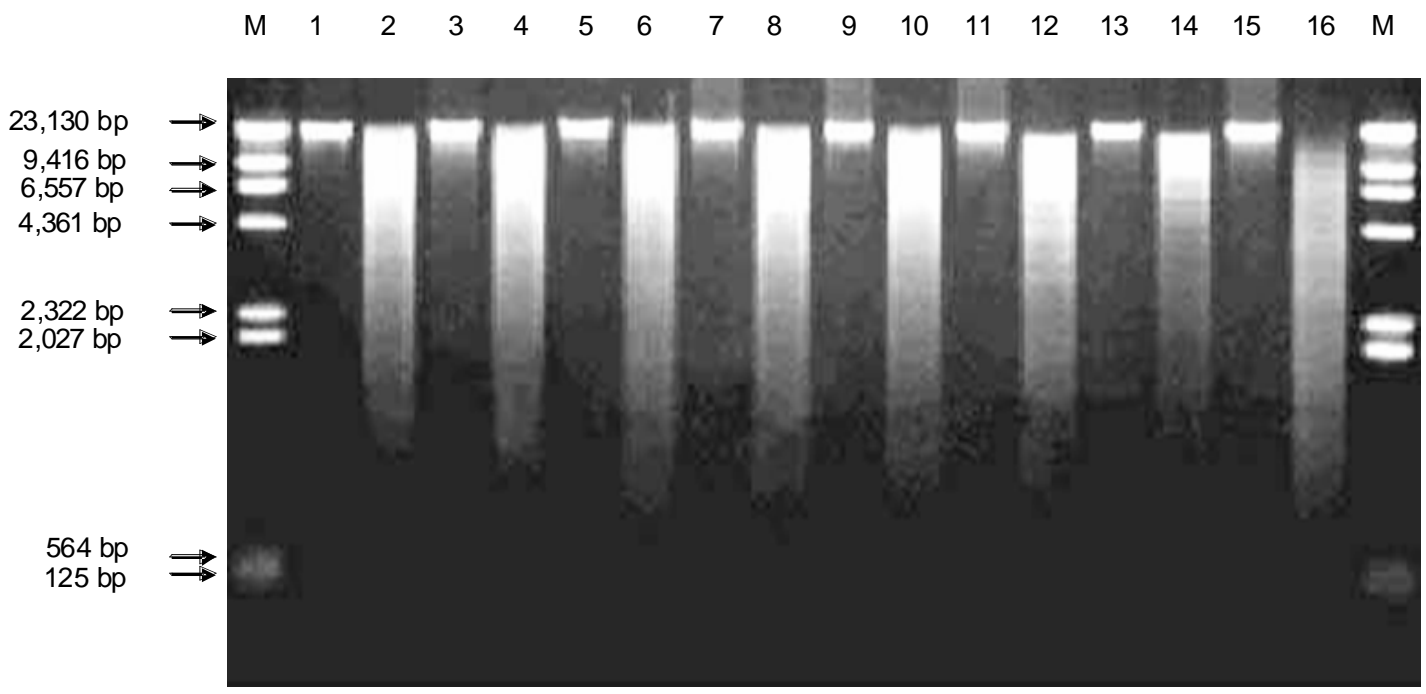

Fig. (1). Genomic DNA prepared from seeds of 8 different cultivars of apple (Malus $s p$.). M: DNA size marker (Hind III digested Lambda DNA). Lanes 1-16, 8 different apple cultivars and their respective restriction digests with EcoR V in adjacent lanes. 1-2: 'Chocolaty'; 3-4: 'Golden Delicious' HP; 5-6: 'Golden Delicious' JK; 7-8: 'Kali Devi'; 9-10: 'Maharaji'; 11-12: 'Punchmukhi'; 13-14: 'Red Delicious' JK; 15-16: Chinese.

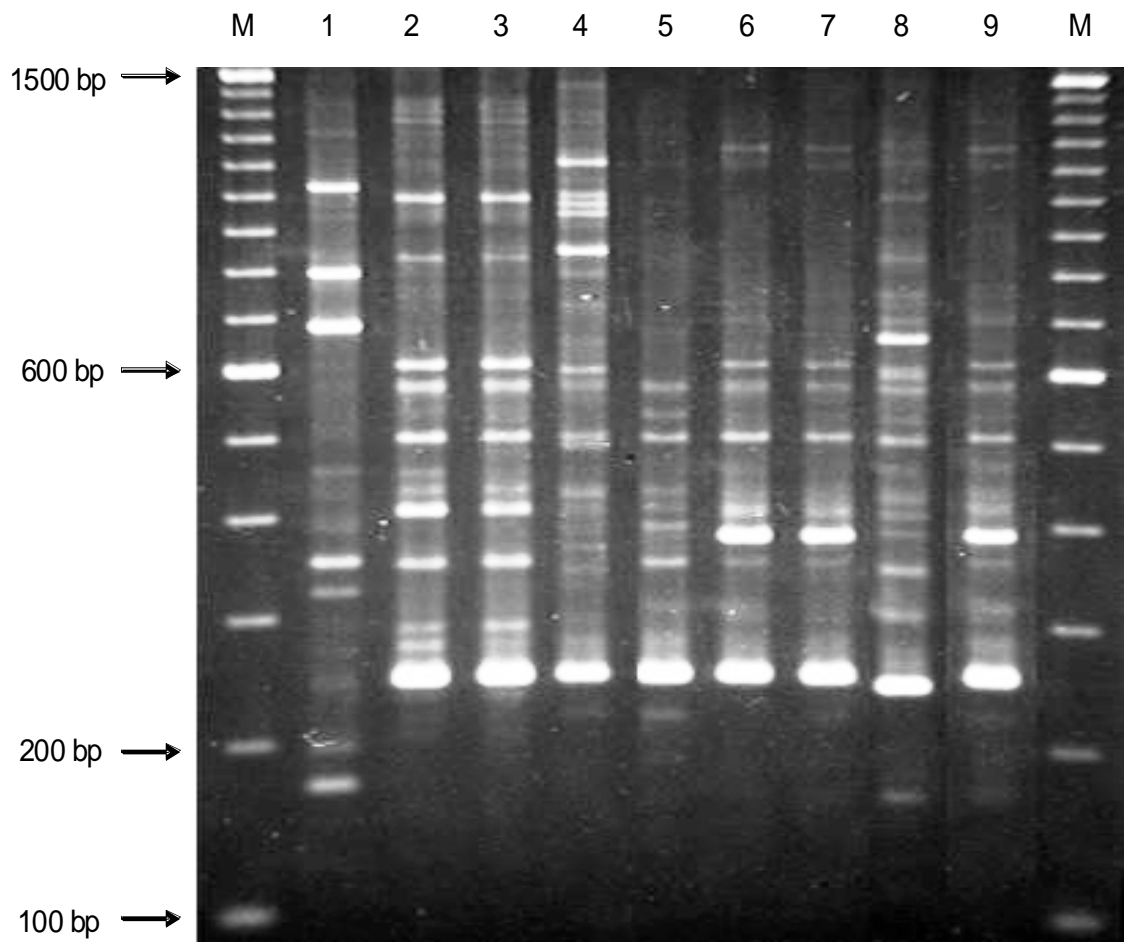

Fig. (2). RAPD profiles of 8 different apple cultivars: PCR reaction was performed as described in Materials and Methods. DNAs were amplified using primer 5'-GTTTCGCTCC-3'. M: $1.5 \mathrm{~kb}$ DNA ladder as marker. Lanes 1-9, 8 different apple cultivars. 1: 'Chocolaty'; 2 : 'Golden Delicious' HP; 3: 'Golden Delicious' JK; 4: 'Kali Devi’; 5: 'Maharaji’; 6-7: 'Punchmukhi’ (duplicate) 8: 'Red Delicious' JK; 9: Chinese.

The quality of DNA was also checked by agarose gel electrophoresis. We observed conspicuous intact bands of high molecular weight DNA (Fig. 1). Several reports have indicated that the presence of RNA can suppress PCR amplification and lead to non-reproducible and unreliable DNA amplification patterns in RAPD analysis [50]. The treatment of
RNase A degrades RNA into small ribonucleosides that are not detectable by gel electrophoresis.

Plant molecular applications such as RAPD, SSR and AFLP necessitate the successful isolation of high quality DNA, devoid of contaminants [39, 51, 52]. Without high quality DNA such downstream molecular manipulations are not feasible. The suitability of extracted DNA for down- 
stream molecular processes was further verified by restriction endonuclease digestion and RAPD-PCR amplification. We successfully digested $1 \mu \mathrm{g}$ of DNA of all eight different cultivars of apple with $20 \mathrm{U}$ of every restriction enzyme such as EcoR V (Fig. 1), Hind III, Dra I, Bam HI, Bgl II and Kpn I (results not shown). The genomic DNA of all eight varieties of apple was highly amplifiable by PCR as indicated by the amplification products resolved on $1.5 \%$ agarose gel (Fig. 2). Although, the RAPD profiles were generated with six primers as reported by Stark-Uranau [47], here we have shown the result with one primer only (5'-GTTTCGCTCC3'). These results further confirmed the purity of the DNA, free of polysaccharide and polyphenol contamination, which would otherwise inhibit the activity of Taq DNA polymerase and restriction endonucleases [39, 52].

Although the experiments were carried out exclusively with eight different apple cultivars, we expect that this protocol might be applicable to all woody plants of Rosaceae family. In addition, this procedure is affordable and does not require sophisticated equipment, making it a superior choice relative to expensive commercial kits for DNA extraction.

\section{CONCLUSION}

In summary, PCR amplifiable high quality DNA extracted from the protocol reported in the current study have the potential to play a very important role in developing strategies for further improvement of Malus species through DNA polymorphism, genome mapping, identification of the QTLs and other plant breeding approaches such as marker assisted breeding.

\section{CONFLICT OF INTEREST}

None declared.

\section{ACKNOWLDGEMENTS}

This work was done at Department of Biotechnology, Deen Dayal Upadhyay Gorakhpur University, Gorakhpur, U.P., India. The authors like to thank Department of Biotechnology, DDU Gorakhpur University for giving necessary support for this work.

\section{ABBREVIATIONS}

$\begin{array}{ll}\text { QTLs } & =\text { Quantitative trait loci } \\ \text { RAPD } & =\text { Random amplified polymorphic DNA } \\ \text { RFLPs } & =\text { Restriction fragment length polymorphisms } \\ \text { SDS } & =\text { Sodium dodecyl sulphate }\end{array}$

\section{REFERENCES}

[1] Boyer, J.; Liu, R.H. Apple phytochemicals and their health benefits. Nutr. J., 2004, 3, 5 .

[2] Knekt, P.; Jarvinen, R.; Seppanen, R.; Heliovaara, M.; Teppo, L.; Pukkala, E.; Aromaa, A. Dietary flavonoids and the risk of lung cancer and other malignant neoplasms. Am. J. Epidemiol., 1997, $146,223-230$.

[3] Le Marchand, L.; Murphy, S.P.; Hankin, J.H.; Wilkens, L.R.; Kolonel, L.N. Intake of flavonoids and lung cancer. J. Natl. Cancer Inst., 2000, 92, 154-160.

[4] Knekt, P.; Jarvinen, R.; Reunanen, A.; Maatela, J. Flavonoid intake and coronary mortality in Finland: a cohort study. Br. Med. J., 1996, 312, 478-481.
Tabak, C.; Arts, I.C.W.; Smit, H.A.; Heederik, D.; Kromhout, D. Chronic obstructive pulmonary disease and intake of catechins, flavonols, and flavones: The MORGEN Study. Am. J. Respir. Crit. Care Med., 2001, 164, 61-64.

[6] Knekt, P.; Isotupa, S.; Rissanen, H.; Heliovaara, M.; Jarvinen, R.; Hakkinen, S.H.; Aromaa, A.; Reunanen, A. Quercetin intake and the incidence of cerebrovascular disease. Eur. J. Clin. Nutr., 2000, 54, 415-417.

[7] Gosse, F.; Guyot, S.; Roussi, S.; Lobstein, A.; Fischer, B.; Seiler, N.; Raul F. Chemopreventive properties of apple procyanidins on human colon cancer-derived metastatic SW620 cells and in a rat model of colon carcinogenesis. Carcinogenesis., 2005, 26(7), 12911295.

[8] McCann, M.J.; Gill, C.I.; O'Brien, G.; Rao, J.R.; McRoberts, W.C.; Hughes, P., McEntee, R.; Rowland, I.R. Anti-cancer properties of phenolics from apple waste on colon carcinogenesis in vitro. Food Chem. Toxicol., 2007, 45(7), 1224-1230.

[9] Hamauzu, Y.; Yasui, H.; Inno, T.; Kume, C.; Omanyuda, M. Phenolic Profile, Antioxidant property, and anti-influenza viral activity of chinese quince (Pseudocydonia sinensis Schneid.), quince ( $C y$ donia oblonga Mill.), and apple (Malus domestica Mill.) Fruits. J. Agric. Food Chem., 2005, 53(4), 928-934.

[10] Eberhardt, M.V.; Lee, C.Y.; Liu, R.H. Antioxidant activity of fresh apples. Nature, 2000, 405, 903-904.

[11] Yang, C.S.; Landau, J.M.; Huang, M.T.; Newmark, H.L. Inhibition of carcinogenesis by dietary polyphenolic compounds. Annu. Rev. Nutr., 2001, 21, 381-406.

[12] Wolfe, K.; Wu, X. Z.; Liu, R. H. Antioxidant activity of apple peels. J. Agric. Food Chem., 2003, 51, 609-614

[13] Yoon, H.; Liu, R.H. Effect of selected phytochemicals and apple extracts on NF- $\kappa \mathrm{B}$ activation in human breast cancer MCF-7 cells. J. Agric. Food Chem., 2007, 55, 3167-3174.

[14] Liu, R.H.; Liu, J.; Chen, B. Apples prevent mammary tumors in rats. J. Agric. Food Chem., 2005, 53, 2341-2343.

[15] Koller, B.; Lehman, A.; McDermott, J.M.; Gessler, C. Identification of apple cultivars using RAPD markers. Theor. Appl. Genet., 1993, 85, 901-904.

[16] Tignon, M.; Kettmann, R.; Watillon, B. AFLP: Use for the identification of apple cultivars and mutants. Acta Hort., 2000, 521, 219226.

[17] Galli, Z.; Halasz, G.; Kiss, E.; Heszky, L.; Dobranszki, J. Molecular identification of commercial apple cultivars with microsatellite markers. Hort. Science, 2005, 40(7), 1974-1977.

[18] Crosby, J.A.; Janick, J.; Pecknold, P.C.; Korban, S.S.; O’Connor, P.A.; Ries, S.M.; Goffreda, S.; Voordeckers, A. Breeding apple for scab resistance. Acta Hort., 1992, 317, 43-70.

[19] Tartarini, S.; Sansavini, S. The use of molecular markers in pome fruit breeding. Acta Hort., 2003, 622, 129-140.

[20] Goulao, L.; Oliveira, C.M. Molecular characterization of cultivars of apple (Malus $\times$ domestica Borkh.) using microsatellite (SSR and ISSR) markers. Euphytica, 2001, 122, 81-89.

[21] Nybon, H.; Schaal, B.A. DNA 'fingerprints' applied to paternity analysis in apples (Malus $x$ domestica). Theor. Appl. Genet., 1990, 79, 763-768.

[22] Watilon, B.; Druart, P.; Du Jardin, P.; Kettmann, R.; Boxus, P.; Burny, A. Use of random cDNA probes to detect restriction fragment length polymorphisms among apple clones. Sci. Hort., 1991, 46, 235-243.

[23] Nybom, H.; Gardiner, S.; Simon, C.J. RFLPs obtained from a rDNA probe and detected with enhanced chemiluminescence in apples. Hort. Sci., 1992, 27, 355-356.

[24] Duneman, F.; Kahnau, R.; Schmidt, H. Genetic relationships in Malus evaluated by RAPD fingerprinting of cultivars and wild species. Plant Breed., 1994, 113, 150-159.

[25] Mulcahy, D.L.; Cresti, M.; Sansavini, S.; Douglas, G.C.; Linskens, H.F.; Mulcahy, G.B.; Vignani, R.; Pancaldi, M. The use of random amplified polymorphic DNAs to fingerprint apple genomes. Sci. Hort., 1993, 54, 89-96.

[26] Harada, T.; Maksukawa, K.; Sato, T., Ishikawa Niizeki, R.; Saito, K.M. DNA-RAPD detect genetic variation and paternity in Malus. Euphytica, 1993, 65, 87-91.

[27] Gardiner, S.E.; Bassett, H.C.M.; Madie, C.; Noition, D.A.M. Isozyme, randomly amplified polymorphic DNA (RAPD), restriction fragmentlength polymorphism (RFLP) markers to deduce a putative parent for the 'Braeburn' apple. J. Am. Soc. Hort. Sci., 1996, $121,996-1001$ 
[28] Autio, W.R.; Schupp, J.R.; Ferree, D.C.; Glavin, R.; Mulcahy, D.L. Application of RAPDs to DNA extracted from apple rootstocks. Hort. Sci., 1998, 33, 333-335.

[29] Ardelean, M.; Mitre, V.; Lukacs, L.; Pop, R.; Mitre, I.; Cordea, M. Efficiency of nonparametric statistics in evaluating phenotypic variability and of RAPD analysis in evaluating variability at the molecular level, of the main apple varieties grown in Transylvania. Bull. USAMV-CN, 2007, 64 (1-2), 29-33.

[30] Durel, C.E.; Parisi, L.; Laurens, F., Van de Weg, W.E.; Liebhard, R.; Jourjon, M.F. Genetic dissection of partial resistance to race 6 of Venturia inaequalis in apple. Genome, 2003, 46, 224-234.

[31] Durel, C.E.; Van de Weg, W.E.; Venisse, J.S.; Parisi, L. Localization of a major gene for apple scab resistance on the European genetic map of the Prima $\times$ Fiesta cross. OILB/WPRS Bull., 2000, 23, 245-248.

[32] Evans, K.M.; James, C.M. Identification of SCAR markers linked to Pl-w mildew resistance in apple. Theor. Appl. Genet., 2003, 106, 1178-1183.

[33] Calenge, F.; Drouet, D.; Denance, C.; Van de Weg, W.E.; Brisset, M.N.; Paulin, J.P.; Durel, C.E. Identification of a major QTL together with several minor additive or epistatic QTLs for resistance to fire blight in apple in two related progenies. Theor.Appl.Genet., 2005, 111, 128-135.

[34] Calenge, F.; Faure, A.; Goerre, M.; Gebhardt, C.; Van de Weg, W.E.; Parisi, L.; Durel, C.E. Quantitative Trait Loci (QTL) analysis reveals both broad-spectrum and isolate-specific QTL for scab resistance in an apple progeny challenged with eight isolates of Venturia inaequalis. Phytopathology, 2004, 94, 370-379.

[35] Gygax, M.; Gianfranceschi, L.; Liebhard, R.; Kellerhals, M.; Gessler, C.; Patocchi, A. Molecular markers linked to the apple scab resistance gene Vbj derived from Malus baccata jackii. Theor. Appl. Genet., 2004, 109, 1702-1709.

[36] James, C.M.; Clarke, J.B.; Evans, K.M. Identification of molecular markers linked to the mildew resistance gene Pl-d in apple. Theor. Appl. Genet., 2004, 110, 175-181.

[37] Patocchi, A.; Bigler, B.; Koller, B.; Kellerhals, M.; Gessler, C. Vr2: a new apple scab resistance gene. Theor.Appl.Genet., 2004, 109, 1087-1092.

[38] Khan, M.A.; Duffy, B.; Gessler, C.; Patocchi, A. QTL mapping of fire blight resistance in apple. Mol. Breed., 2006, 17, 299-306.

[39] Moyo, M.; Amoo, S.O.; Bairu, M.W.; Finnie, J.F.; Van Staden, J. Optimising DNA isolation for medicinal plants. South Afr. J. Bot., 2008, 74, 771-775.
[40] Pirttila, A.M.; Hirsicorpi, M.; Kamarainen, T.; Jakkola, L.; Hohtala, A. DNA isolation method for medicinal and aromatic plants. Plant Mol. Biol. Rep., 2001, 19, 273a-273f.

[41] Mishra, K.M.; Rani, S.N.; Ram, A.S.; Sreenath, H.L. A simple method of DNA extraction from coffee seeds suitable for PCR analysis. Afr. J. Biotechnol., 2008, 7, 409-413.

[42] Varma, A.; Padh, H.; Shrivastava, N. Plant genomic DNA isolation: an art or a science. Biotechnol. J., 2007, 2, 386-392.

[43] Barnell, P.; Blanchard, A.N.; Bryant, J.A.; Smirnoff, N.; Weir, A.F. Isolation of DNA from the highly mucilaginous succulent plant $S e$ dum telephium. Plant Mol. Biol. Rep., 1998, 16, 133-138.

[44] Diadema, K.; Baumel, A.; Lebris, M.; Affre, L. Genomic DNA isolation and amplification from callus culture in succulent plants, Carpobrotus species (Aizoaceae). Plant Mol. Biol. Rep., 2003, 21, 173a-173e.

[45] Lu, Y.; Foo, L.Y. Constitution of some chemical components of apple seed. Food Chem., 1998, 61(1), 29-33.

[46] Kim, C.S.; Lee, C.H.; Shin, J.S.; Chung, Y.S.; Hyung, N.I. A simple and rapid method for isolation of high quality genomic DNA from fruit trees and conifers using PVP. Nucleic Acids Res., 1997 25(5), 1085-1086.

[47] Stark-Urnau, M. Use of RAPD-markers in Malus $\times$ domestica (apple) and Pyrus communis (pear) for cultivar identification - Part I: Malus $\times$ domestica (apple). Erwerbsobstbau, 2002a, 44, 139144.

[48] Pasakinskiene, I.; Pasakinskiene, V. Floral meristems as a source of enhanced yield and quality of DNA in grasses. Plant Cell Rep., 1999, 18, 490-492.

[49] Weising, K.; Nybom, H.; Wolff, K.; Kahl, G. DNA Fingerprinting in Plants: Principles, Methods and Applications, $2^{\text {nd }}$ ed.; CRC Press: Boca Raton, 2005.

[50] Porebski, S.; Bailey, L.G.; Baum, B.R. Modification of CTAB DNA extraction protocol from plants containing high polysaccharide and polyphenol components. Plant Mol. Biol. Rep., 1997, 15, 8-15.

[51] Michiels, A.; Van den Ende, W.; Tucker, M.; Van Riet, L.; Van Laere, A. Extraction of high-quality genomic DNA from latexcontaining plants. Anal. Biochem., 2003, 315, 85-89.

[52] Ahmad, S.M.; Ganaie, M.M.; Qazi, P.H.; Verma, V.; Basir, S.F.; Qazi, G.N. Rapid DNA isolation protocol for angiospermic plants. Bulgarian J. Plant Physiol., 2004, 30, 25-33.

Received: November 27, 2011

(C) Ansari and Khan; Licensee Bentham Open.

This is an open access article licensed under the terms of the Creative Commons Attribution Non-Commercial License (http://creativecommons.org/ licenses/ by-nc/3.0/) which permits unrestricted, non-commercial use, distribution and reproduction in any medium, provided the work is properly cited. 